\title{
Naloge prosvetne oblasti v Sloveniji in Evropi
}

\author{
Ana Krajnc
}

\begin{abstract}
Slovenija je bila vključena $v$ mednarodno raziskavo o prihodnosti izobraževanja odraslih v Evropi, imenovano projekt EURODELPHI. Namen raziskave je bil, katere so poglavitne naloge prosvetnih oblasti in ali jih izpolnjujejo.
\end{abstract}

Raziskava je dobila ime po raziskovalni metodi DELPHI, pri kateri sodelujejo in napovedujejo spremembe in razvoj strokovnjaki, torej ljudje, ki o raziskovanih pojavih zares največ vedo. Veliko znanja imajo že iz preteklosti, zato so njihove napovedi za prihodnost razmeroma zanesljive. V Sloveniji in drugih sodelujočih državah so odgovarjali na vprašanja izobraževalci, raziskovalci, politiki in novinarji poročevalci (Jelenc S.,1995).

Za obravnavano temo so bili pomembni zlasti odgovori na tri vprašanja:

- katere so poglavitne naloge prosvetnih oblasti,

- v kolikšni meri prosvetne oblasti te naloge potem tudi izpolnjujejo,

- kako dobro jih izpolnjujejo.

Poleg razčlembe odgovorov iz Slovenije obravnavamo podatke še na dveh ravneh, in sicer jih primerjamo s podatki iz nekdanjih socialističnih državah (Estonije in Češke) in s podatki iz drugih evropskih držav oziroma pokrajin.

\section{Prosvetna polihik}

Prosvetna politika je v današnjem svetu žgoča tema, ker je zaradi nepretrganih sprememb v okolju težko presoditi, kateri izobraževalni program je pravi. Casa, da bi popravljali nove napake, ni več, ker postaja v družbi informatike znanje ena poglavitnih gonilnih sil preživetja. Razmere $\mathrm{v}$ praksi odsevajo mnoge napake, storjene $\mathrm{v}$ politiki šolskega sistema in izobraževanja $\mathrm{v}$ preteklosti. V prihodnost lahko zremo s strahom in zaskrbljenostjo zlasti zaradi velikega pomanjkanja znanja med ljudmi.

Upravičeno se vprašamo, kakšno izročilo imamo v prosvetni politiki. Prosvetna politika v Jugoslaviji nikoli ni bila posebna celota. Zmeraj je bila del splošne partijske politike in ta je imela vso moč odločanja. Najbolj karikiran primer je bila reforma usmerjenega izobraževanja, ko so partijski veljaki utišali ministre in direktorje zavodov za šolstvo iz posameznih republik pa tudi znanstvenike $\mathrm{z}$ univerz. Mnenja učiteljev in staršev ni nihče upošteval. Z nekaj privrženci so v izobraževanju izpeljali, kar so hoteli. Nadzor nad izobraževanjem je bil ena poglavitnih nalog partije. Pritisk je bil najhujši po partijskem kongresu leta 1976, ko so iz strahu pred propadom države zavirali naraščanje intelektualnega potenciala, omejevali šolski sistem in zatirali izobraževanje odraslih. Takrat je oblast prevzelo skrajno desno partijsko krilo in zadušilo še zadnje demokratične pobude. Sprejeli so celo posebno, takrat zelo razvpito, resolucijo o vzgoji in izobraževanju in jo dosledno uresničevali vse do razpada države.

Zanimivo je, da nekdanja Jugoslavija nikoli ni imela zveznega ministrstva za šolstvo, kar je bilo na videz zelo demokratično, saj naj bi vzgojo urejali v okviru posameznih republik oziroma narodov. S tem si je država celo ustvarjala del svojega zunanjega ugleda. Kljub temu pa se je vse odločalo v Beogradu, tudi brez ministrstva. Vzgoja je bila partijska zadeva. Danes vemo, da ne more biti nobenega pravega izobraževanja, ne da bi poznali in upoštevali potrebe ljudi po znanju. Učinkovito prosvetno politiko lahko oblikujemo le od spodaj navzgor, sicer zatremo razvoj ljudskih zmožnosti ali »človeških virov«.

Politično prebujanje konec osemdesetih let in nastanek nove države sta izobrazbi vrnila pomen. Šolski sistem in izobraževanje odraslih sta hitro oživljala. Izobraževanju so se odprla vrata tudi prek hitro rastočega zasebnega sektorja in s pomočjo izobraževanja v tujini. Razvoj zahteva veliko znanja. Družbeni in gospodarski cilji omogočajo, da določimo, katero znanje je potrebno. $\mathrm{V}$ javnosti vlada zaupanje $\mathrm{v}$ prosvetno politiko, izobraževanja, vzgojo, širjenje možnosti za učenje, v šolski sistem in andragoško prakso. Prosvetna politika pri nas nastaja na novo, kot posebno zaokroženo področje državnega delovanja se šele oblikuje. Upoštevati je treba nove dejavnike, kot so družbene razlike, nastajanje novih panog, prezaposlovanje v kratkih časovnih obdobjih, preoblikovanje gospodarstva in nastajanje novih vrednot, ki temeljijo na prebujanju kulture.

\section{Izidi faktorske analize o nalogah oblasti}

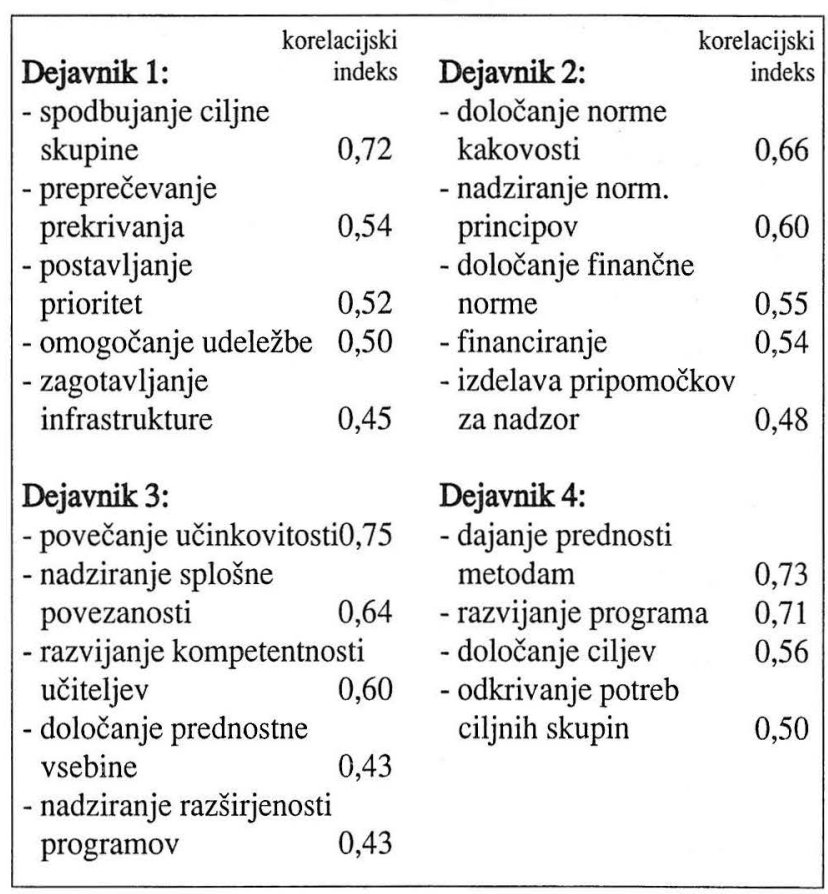


Prosvetna politika se ne more ozko vezati samo na proizvodni proces, kot se je v prejšnjih desetletjih. Razvoj ljudi temelji na kulturi in dejavnem udejstvovanju v okolju.

\section{Naloge oblasti in uresničevanje prosvetne polinilke v Sloveniji}

Podatki iz 16 držav in pokrajin o nalogah oblasti in uresničevanju prosvetne politike so pokazali zelo različna pričakovanja, medtem ko so ocene o kakovosti opravljanja nalog zelo podobne v vseh državah in so na meji spodnje tretjine. (Glej grafikon 1)

Faktorska analiza je izločila štiri dejavnike, ki jih navajamo skupaj s korelacijskimi indeksi.

Vsebinsko se posamezni dejavniki zelo razlikujejo in kažejo velike razlike v pričakovanih nalogah oblasti. Dejavnik 1 združuje naloge, ki bi olajšale izobraževanje odraslih in podpirale razvoj, dejavnik 2 ima vlogo splošnega načrtovanja, dejavnik 3 predvideva med nalogami oblasti zlasti nadzorno funkcijo, nadzor in financiranje, dejavnik 4 je osredinjen na naloge za izboljševanje izobraževalne ponudbe.

Odgovori iz Slovenije so se izrazito osredinili na nekatere najpomembnejše naloge oblasti. (Glej grafikon 1)

\begin{tabular}{lrr}
\hline Naloge & Pomembnost & Opravljanje \\
\hline - financiranje & $100 \%$ & $89 \%$ \\
\hline - določanje prednosti & $98 \%$ & $64 \%$ \\
\hline - nadziranje principov & $97 \%$ & $61 \%$ \\
\hline - postavljanje finančnih norm & $96 \%$ & $76 \%$ \\
\hline - usklajevanje ponudbe & $95 \%$ & $47 \%$ \\
\hline - zagotavljanje infrastrukture & $94 \%$ & $68 \%$ \\
\hline
\end{tabular}

Funkcijo oblasti vidijo anketirani v naši družbi predvsem v financiranju, nadzorovanju in izobraževanju in postavljanju norm. O teh nalogah tudi menijo, da jih oblast $v$ največji meri izpolnjuje. Strokovnjake bolj vidijo v vlogi izvrševalcev tistega, kar je oblast odločila. Oblasti prepuščajo odločitve o izobraževanju odraslih. Ti podatki kažejo, kako počasna je demokratizacija naše družbe.

Anketirani v razvitih državah pripisujejo oblasti nalogo usklajevanja in skrb za dobro izobraževanja, skrb za posebne odrinjene ciljne skupine in učinkovitost učenja. Take naloge pa postavljajo oblast $\mathrm{v}$ povsem drugačen položaj in jo vpnejo $\mathrm{v}$ demokratična razmerja.

Strokovnjaki s svojimi stališči in ocenami o najpomembnejših nalogah porivajo oblast $\mathrm{v}$ avtokratski in represivni model vladanja. O drugačnem, bolj demokratičnem vodenju verjetno še nimajo dovolj znanja. Ne predstavljajo si, da bi se morala oblast vživljati v ljudi, odkrivati njihove potrebe po znanju, razvijati programe, pospeševati uvajanje novih metod in preprečevati prekrivanje programov v izobraževanju odraslih. Naštete naloge so v Sloveniji navajali le redki strokovnjaki, v razvitejšem in bolj demokratičnem okolju pa so to najpomembnejše naloge oblasti.

$\mathrm{V}$ demokratični družbi ima oblast več vsebinskega dela in odgovornosti za uspešnost in obrobne skupine, medtem ko se avtokratsko vodenje omeji na predpisovanje norm in nadzor. Od štirih s faktorsko analizo prepoznanih dejavnikov prevladuje $\mathrm{v}$ Sloveniji dejavnik 3 - financiranje in nadzor. (Glej grafikon 2)

Izpolnjevanje nalog je mnogo slabše od izražene pomembnosti nalog oblasti. Razhajanje med pričakovanji in izpolnitvijo opozarja na neuspeh oblasti. Razlike dosežejo tudi več kot 50 odstotkov.

Po mnenjih iz ankete izpolnjuje oblast v Sloveniji predvsem eno nalogo: financira izobraževanje odraslih (razlika med

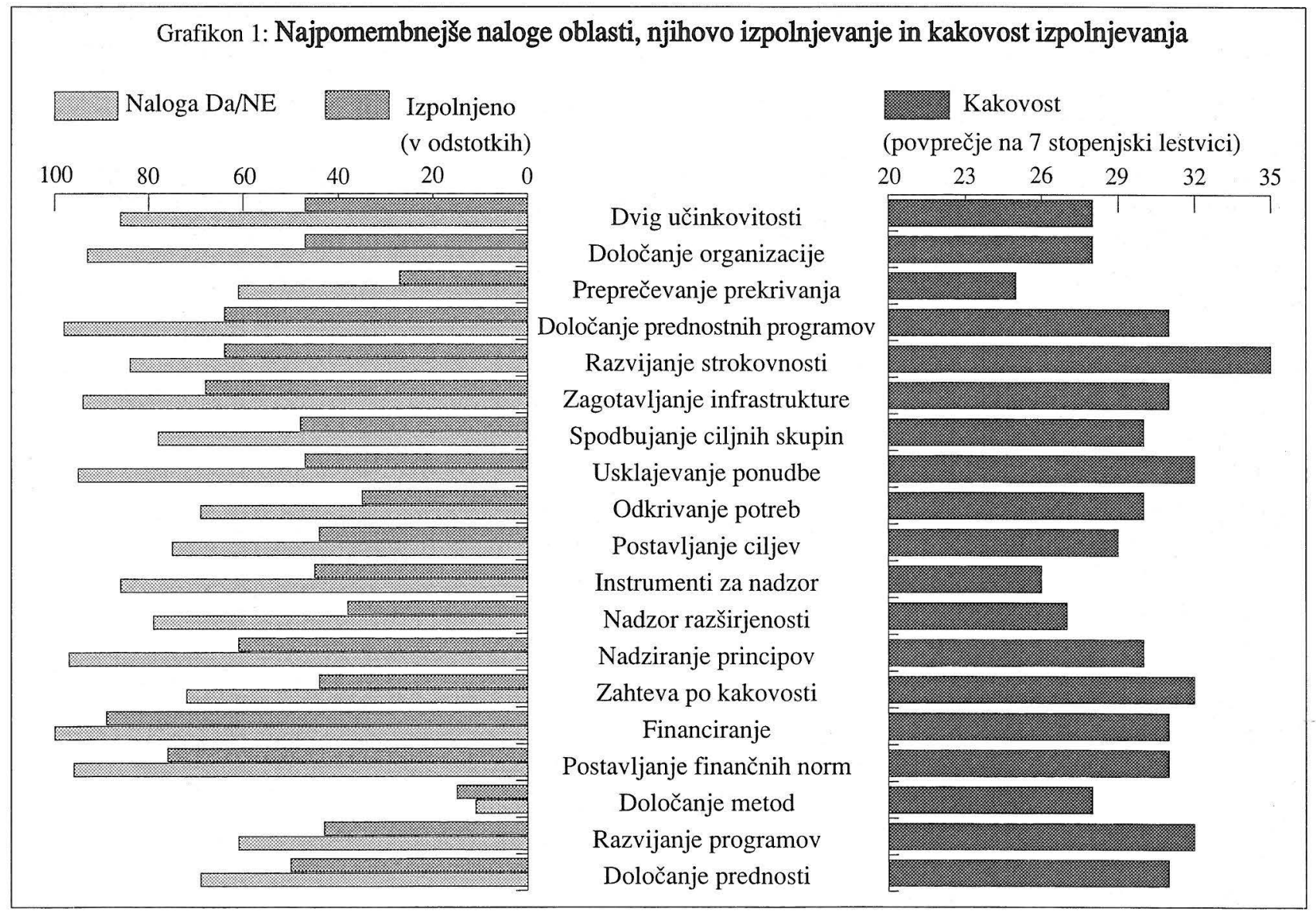




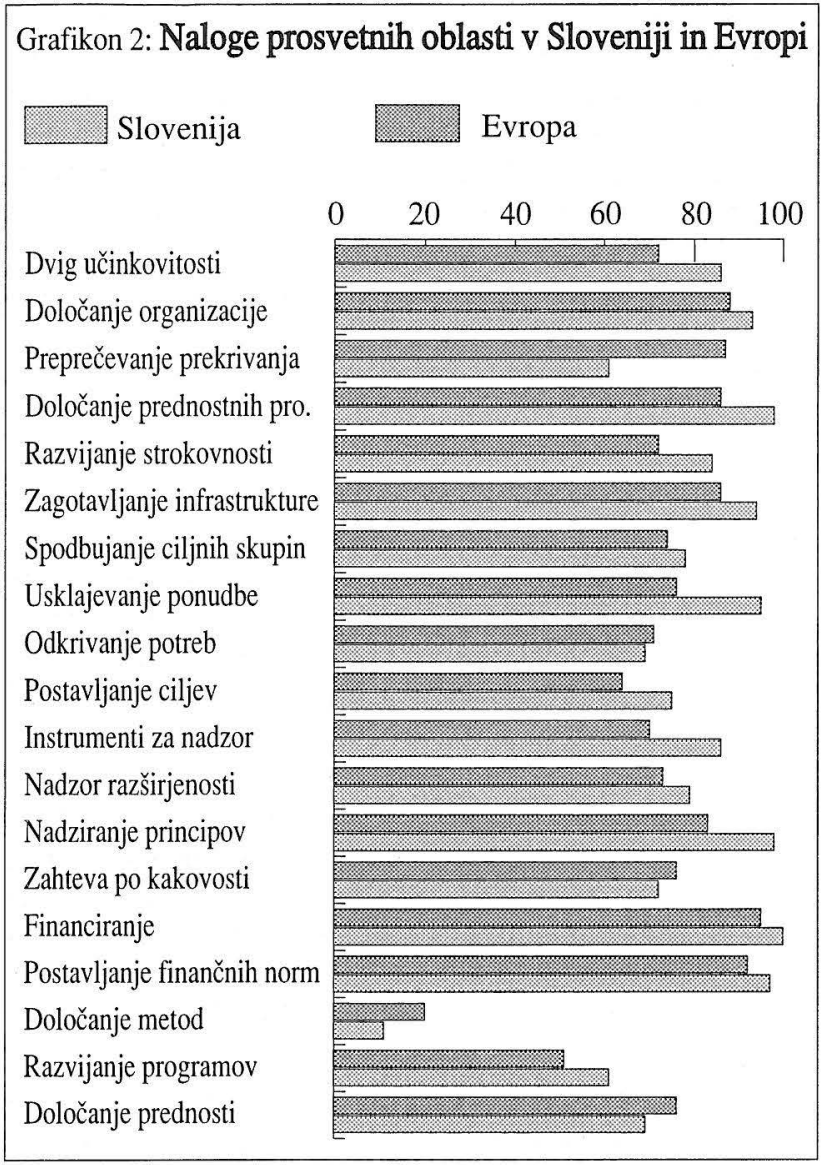

pomembnostjo naloge in njenim opravljanjem je 20 odstotkov). Druge naloge, čeprav po oceni pomembne, izpolnjuje slabše. Najslabše skrbi oblast za usklajevanje ponudbe (razlika je 53 odstotkov). Izpolnjevanje nalog oblasti v povprečju pade za 30 odstotkov pod pomembnost nalog.

Skupine strokovnjakov so ocenjevale tudi, kako dobro oblast izpolnjuje svoje naloge. Odgovori so si zelo podobni v slovenskem vzorcu in v drugih evropskih vzorcih. Kaže, da si strokovnjaki ne jemljejo pravice, da bi ocenjevali prosvetno oblast. Vse ocene so nekoliko pod srednjo vrednostjo. Na lestvici 7 je povprečna ocena $3 \mathrm{z}$ minimalnimi odstopanji. V ocenah se izraža konformizem in izogibanje dejanski presoji, saj je nemogoče, da bi oblast vse naloge enako (slabo) opravljala.

\section{Naloge oblasti v evropskih državah}

Med odgovori posameznih skupin strokovnjakov iz raznih držav ni velikih razlik. Primerjalna razčlemba je pokazala, da so $\mathrm{v}$ ocenah nekoliko bolj pozitivni politiki in da so ženske dosti bolj kritične kot moški. Lestvica pri oceni kakovosti opravljanja nalog se pri ženskah bolj diferencira in doseže tudi zelo pozitivne ali zelo negativne odgovore, odvisno od naloge.

Anketirani ugotavljajo, da pri tistih nalogah, za katere menijo, da so manj pomembne, tudi oblast naredi zelo malo. Ne posega $\mathrm{v}$ način izobraževanja, $v$ metode dela, ne posveča posebne skrbi prekrivanju programov in ne ugotavlja dejanskih potreb ljudi. (Glej grafikon 2).

Strokovnjake in širšo javnost gotovo zanima, kje je v Sloveniji največje razhajanje med pričakovanimi nalogami oblasti in njihovim uresničevanjem. Največje so razlike pri naslednjih nalogah:

- usklajevanje ponudbe (48 odstotkov razlike),

- organizacija infrastrukture (46 odstotkov razlike),

- nadzor izobraževanja (41 odstotkov razlike),

- postavljanje norm in nadziranje (41 odstotkov razlike).

Da bi bilo uresničevanje teh nalog boljše, mora imeti prosvetna oblast jasne cilje in celovit koncept prosvetne politike. Brez tega ni mogoče pričakovati usklajevanja in vlaganja v infrastrukturo.

Pomanjkljive povratne informacije oblasti ne omogočajo pregleda nad dogajanjem v praksi. Zato je nadzor nad izvajanjem programov razmeroma slab. Slab je tudi nadzor nad uresničevanjem postavljenih norm. Nalogi nadziranja in preverjanja izvajanja nista jasni, če politiki poleg povratnih informacij nimajo tudi jasnih ciljev.

V Evropi so bolj kot v Sloveniji poudarjene naslednje naloge oblasti (glej grafikon 2):

- preprečevanje prekrivanja programov

- določanje metod,

- določanje prednostnih programov,

- zahteva po kakovosti izobraževanja,

- odkrivanje izobraževalnih potreb.

Po podatkih iz drugih evropskih držav prosvetna oblast predvsem financira izobraževanje odraslih, ima pa tudi razvojno vlogo in skrbi za usklajevanje. Spuščala naj bi se v vsebino izobraževanja in oblike, da bi dejavnost približala potrebam ljudi. V družbeno bolj zaostalih okoljih se poleg financiranja poudarja še nadzor nad izobraževanjem.

Stališča strokovnjakov so odsev družbene zavesti. Oblikujejo družbeno ozračje, ki se širi med ljudmi, zlasti med udeleženci izobraževanja. Stališča vplivajo na pričakovanja. Če strokovnja-

\section{Grafikon 3: Kako dobro oblasti opravljajo svoje naloge?}

Primerjava Slovenije z drugimi evropskimi državami

Slovenija

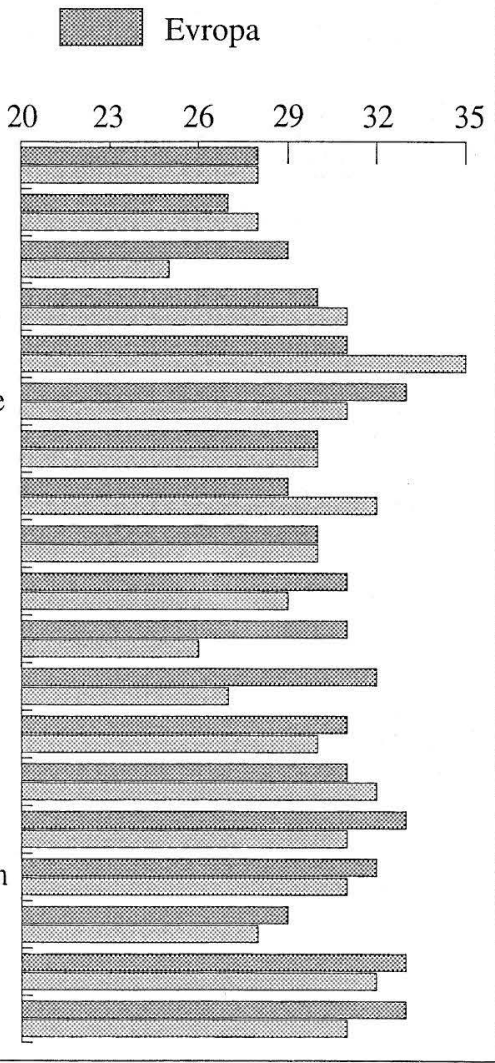




\section{Grafikon 4: Težave, ki jih imajo ljudje in prispevek izobraževanja odraslih}

Slovenija
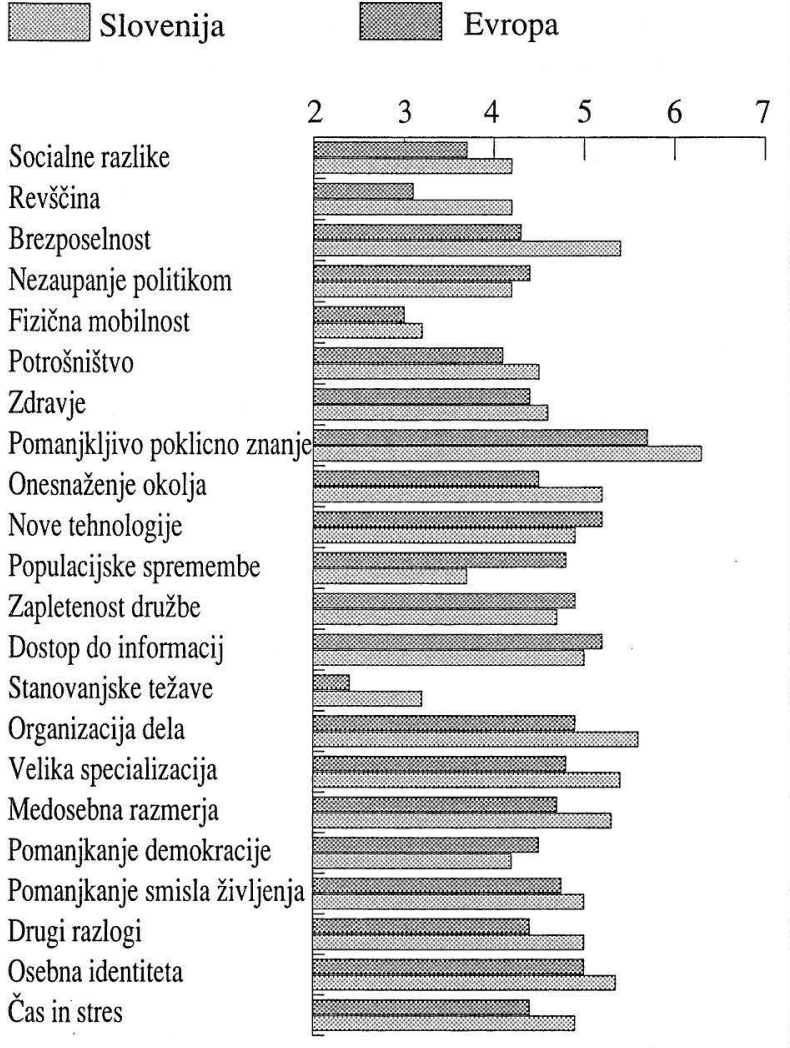

ki menijo, da oblasti neka funkcija ne pripada, jo v stikih s predstavniki oblasti ne bodo poudarjali, še manj, da bi jo zahtevali.

Stališča oblikujejo javno mnenje, ki se kot družbeni stereotip razširi med ljudi. Postane način odzivanja in merilo za zadovoljstvo ali nezadovoljstvo. Prenaša se samodejno $\mathrm{z}$ osebe na osebo. Posameznik se ne vpraša več, ali je tako stališče zares pravilno. Sprejema ga samodejno, ker to zahteva manj truda, kot če bi si hotel sam nekaj pojasniti. Ker se pojavi v okolju z razvojem čedalje hitreje spreminjajo, prevzeti stereotipi zmanjšujejo porabo psihične energije in napor zaradi nepretrganega prilagajanja okolju. (McLuhan, 1971)

McLuhan pravi, da je enoznačno kodiranje in razlaganje pojavov značilno za industrijo pred avtomatizacijo. $\mathrm{V}$ dobi avtomatizacije se tudi pojavi človekove zavesti razpršijo.

Oblikujejo se skupine ljudi, ki zelo različno mislijo. Elektronska oprema omogoča sprotno prepoznavanje razlik in sprememb. Množična občila hitro prenašajo stališča in močno vpliva na odločanje. Kdor ima občila, ima oblast. Predvsem od občil je odvisna demokratizacija stališč do oblasti tudi pri nas. Ali bo oblast dosegla cilje prek financiranja in nadzora ali s spodbujanjem usklajevanja in upoštevanjem težav, ki jih ljudje imajo? Ali bo oblast sama sebi namen in bo skrbela predvsem zato, da se ohrani, ali pa bo v svoje delo vnesla predvsem vsebine in se bo zavzemala za doseganje ciljev? (McLuhan,1964)

Oblikovanje stališč je psihodinamičen proces. Oblast ustvarja določen vtis in uporablja metode nadzora in pritiska. Ljudje se ne odzovejo s svojo drugačno zamislijo, temveč vsiljen vzorec razmerij sprejmejo. Delujejo tako, kot jim narekujejo, ne da bi razmislili, ali je to za rešitev težav zares koristno. Ker popustijo pritisku oblasti, se njihove potrebe in pričakovanja sploh ne izrazijo. Igra odločitev je enostranska, ker v njej sobesednik, človek s svojimi potrebami po znanju, sploh ni navzoč.
Za bolj demokratične odnose je potrebno delovanje obeh strani: pritiski od zgoraj in od spodaj, celosten pogled na razmere in celosten načrt akcije od zgoraj, potrebe ljudi in močne poti razreševanja od spodaj. Podoba o izobraževanju, ki bi nastajala samo po eni poti in brez dialoga med oblastjo in ljudmi, je enostranska. Služi lahko le začasnemu ohranjanju oblasti, ne pa dolgoročnemu razreševanju težav.

\section{Pričakovana prosvetna politika $v$ treh nekdanijh socialističnih državah, sodelujočih v projekłu EURODELPHI, Estoniii, Češki in Sloveniii}

S pričakovanji, kaj mora oblast izpolnjevati, so anketirani najbolj obremenili prosvetne politike v Sloveniji, sledi pa Estonija. Najmanj pričakujejo od oblasti na Češkem. Zlasti strokovnjaki ne privolijo $\mathrm{v}$ to, da bi oblast nadzirala razširjenost izobraževanja, ugotavljala potrebe in usklajevala ponudbo in ciljne skupine ter razvijala strokovnost in učinkovitost izobraževanja odraslih. V vseh treh državah poudarjajo kot najpomembnejše naloge oblasti financiranje, določanje norm za financiranje in določanje tega, kateri programi bodo imeli prednost. (Glej grafikon 5).

Odnos do oblasti je v obravnavanih državah zelo različen, bliže so si stališča v Estoniji in Sloveniji in poudarjajo samo najbolj izstopajoče naloge nadzora in financiranja. Na Ceškem so naloge prosvetnih oblasti razdeljene bolj enakomerno. $\mathrm{V}$ obeh novih državah si strokovnjaki od prosvetnih oblasti veliko več obetajo kot v drugih državah, kjer hočejo tudi strokovnjaki sami odločati.

Tudi ocene o tem, kako prosvetne oblasti predvidene naloge izpolnjujejo, so različne in nihajo do 60 odstotkov. (Glej grafikon 6).

\section{Grafikon 5: Naloge prosvetnih oblasti v Estoniji Ceski in Sloveniji}

Slovenija

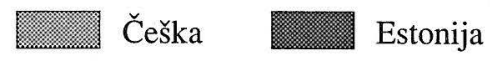

Določanje prednosti

Razvoj programov

Določanje metod

Postavljanje finančnih norm

Sofinanciranje

Zahteva kakovosti

Nadzor principov

Nadzor razširjenosti

Instrumenti nadzora

Postavljanje ciljev

Odkrivanje potreb

Usklajevanje ponudbe

Spodbujanje ciljnih skupin

Zagotavljanje infrastrukture

Razvoj strokovnosti

Določanje pomembnosti

Prekrivanje programov

Organizacija

Dvig učinkovitosti

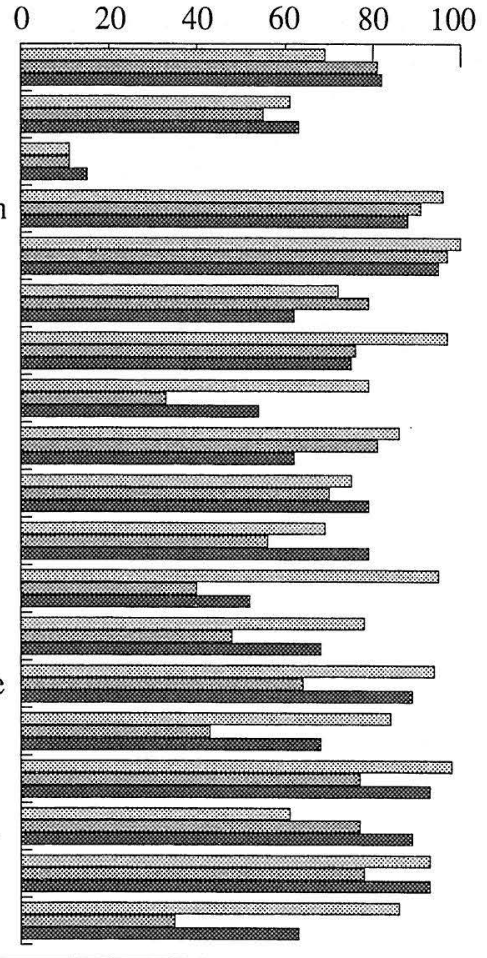




\section{Grafikon 6: Izpolnjevanje nalog oblasti v Estoniji, Ceški in Sloveniji}

lin Slovenija
Določanje prednosti
Razvoj programov

Med vsemi tremi državami so najbolj ugodne ocene v Sloveniji in v povprečju za 20 odstotkov presegajo Estonijo in Češko. Ocene na Češkem so tudi sicer zelo zmerne in nižje. Na Češkem menijo, da oblast najslabše skrbi za učinkovitost izobraževanja, dvig učinkovitosti, spodbujanje ciljnih skupin, usklajevanje ponudbe in nadzor nad razširjenostjo programov.

V Sloveniji so ocene o izpolnjevanju nalog padle pod 60 odstotkov le pri usklajevanju ponudbe (52 odstotkov) in pri nadzoru nad razširjenostjo programov (54 odstotkov). Vse druge ocene o izpolnjevanju nalog so v Slovenji med 65 in 97 odstotki. Enotna ocena v vseh treh državah je, da oblasti slabo skrbijo za uvajanje sodobnih izobraževalnih metod.

dr. Ana Krajnc

redna profesorica na Filozofski fakulteti v Ljubljani

\section{Lifierature}

Jelenc, S. (1995): Prihodnost izobraževanja odraslih - metodološki pristop in opis vzorca, Andragoška spoznanja, št. 3-4, 1995, str. 39-44

Mijoč, N. (1995): Prihodnost izobraževanja odraslih v Evropi - inovacije in oblike sodelovanja z Evropo, Andragoška spoznanja, št. 3-4, 1995, str. 44-55

Marja, T. in Vooglaid Ulo (1995): Education of Adults: The Estonian Report, Talin, Talin Pedagogical University

Krajnc, A. (1995): Prihodnost izobraževanja odraslih v Sloveniji, Ljubljana, Filozofska fakulteta, monografija raziskave

Krajnc, A. (1994): Širše sodelovanje za hitrejšo pot do cilja, Delo, Priloga Znanost in tehnologija, Ljubljana, 15. maj 1994

Leirman, W. in Fache, W. (1992): Towards a supply that covers the demand and a better coordinated policy of life-long learning in Flanders, Leuven, Catholic University of Leuven

Leirman, W. (1995): The future goals and policies of adult education in Europe 1995, Leuven, Catholic University Leuven

Kontiaininen S. (1995): Dynamic Concept Analysis (DCA), Helsinki, University of Helsinki, Department for Education

Carey, L. (1995): EURODELPHI study - the national report for Ireland, Dublin, University of Dublin

Chefin, W. W. in Talley, W. K. (1980): Individual Stability in Delphi Studies, Technological Forecasting and Social Change, Elsevier, North Holland

Rauch, W. (1979): The Decission Delphi, Technological Forecasting and Social Change, Elsevier North Holland

Wodenberg, F. (1991): An Evaluation of Delphi, Elsevier Science Publishing McLuhan, M. (1971): Poznavanje opštila - čovekovih produžetaka, Beograd, Prosveta 